\title{
Trophic niches of a seabird assemblage in Bass Strait, south- eastern Australia
}

\author{
Aymeric Fromant ${ }^{\text {Corresp., } 1,2}{ }^{,}$, Nicole Schumann ${ }^{1}$, Peter Dann ${ }^{3}$, Yves Cherel $^{2}$, John P Y Arnould ${ }^{1}$ \\ ${ }^{1}$ School of Life and Environmental Sciences, Deakin University, Burwood, VIC, Australia \\ ${ }^{2}$ Centre d'Edutes Biologiques de Chizé (CEBC), UMR 7372 du CNRS - La Rochelle Université, Villiers-en-bois, France \\ 3 Research department, Phillip Island Nature Parks, Cowes, VIC, Australia \\ Corresponding Author: Aymeric Fromant \\ Email address: afromant@deakin.edu.au
}

The foraging niches of seabirds are driven by a variety of factors, including competition for prey that promotes divergence in foraging niches. Bass Strait, south-eastern Australia, is a key region for seabirds, with little penguins Eudyptula minor, short-tailed shearwaters Ardenna tenuirostris, fairy prions Pachyptila turtur and common diving-petrels Pelecanoides urinatrix being particularly abundant in the region. The trophic niches of these species were investigated using isotopic values in whole blood and by identifying prey remains in stomach contents. The four species occupied different isotopic niches that varied between 3 years and 3 regions. Little penguins consumed mainly fish whereas the three procellariforms primarily consumed coastal krill Nyctiphanes australis. The dietary similarities between the procellariforms suggest that food resources are segregated in other ways, with interspecific differences in isotope niches possibly reflecting differential consumption of key prey, divergent foraging locations and depth, and differences in breeding phenology. Because oceanographic changes predicted to occur due to climate change may result in reduced coastal krill availability, adversely affecting these seabird predators, further information on foraging zones and feeding behaviour of small procellariform species is needed to elucidate more fully the segregation of foraging niches, the capacity of seabirds to adapt to climate change and the potential for interspecific competition in the region. 
1 Trophic niches of a seabird assemblage in Bass Strait, south-eastern Australia

2

3 Aymeric Fromant ${ }^{1,2}$, Nicole Schumann ${ }^{1}$, Peter Dann $^{3}$, Yves Cherel ${ }^{2}$ and John P.Y. Arnould ${ }^{1}$

$4{ }^{1}$ School of Life and Environmental Sciences, Deakin University, 221 Burwood Hwy, Burwood, 5 VIC 3125, Australia

$6 \quad{ }^{2}$ Centre d'Etudes Biologiques de Chizé (CEBC), UMR 7372 du CNRS - La Rochelle

7 Université, 79360 Villiers en Bois, France

$8{ }^{3}$ Research Department, Phillip Island Nature Parks, PO Box 97, Cowes, VIC 3922, Australia 9

10 Corresponding author:

11 Aymeric Fromant ${ }^{1,2}$

12 School of Life and Environmental Sciences, Deakin University, 221 Burwood Hwy, Burwood, 13 VIC 3125, Australia

14 Email address: afromant@deakin.edu.au 


\section{ABSTRACT}

16 The foraging niches of seabirds are driven by a variety of factors, including competition for prey

17 that promotes divergence in trophic niches. Bass Strait, south-eastern Australia, is a key region

18 for seabirds, with little penguins Eudyptula minor, short-tailed shearwaters Ardenna tenuirostris,

19 fairy prions Pachyptila turtur and common diving-petrels Pelecanoides urinatrix being

20 particularly abundant in the region. The trophic niches of these species were investigated using

21 isotopic values in whole blood and by identifying prey remains in stomach contents. The four

22 species occupied different isotopic niches that varied among years, seasons and regions. Little

23 penguins consumed mainly fish whereas the three procellariforms primarily consumed coastal

24 krill Nyctiphanes australis. The dietary similarities between the procellariforms suggest that food

25 resources are segregated in other ways, with interspecific differences in isotope niches possibly

26 reflecting differential consumption of key prey, divergent foraging locations and depth, and

27 differences in breeding phenology. Because oceanographic changes predicted to occur due to

28 climate change may result in reduced coastal krill availability, adversely affecting these seabird

29 predators, further information on foraging zones and feeding behaviour of small procellariform

30 species is needed to elucidate more fully the segregation of foraging niches, the capacity of

31 seabirds to adapt to climate change and the potential for interspecific competition in the region. 
32

33

34

35

\section{INTRODUCTION}

Seabirds are major consumers of marine biomass, feeding on a variety of fish, cephalopods and crustaceans (Ridoux 1994, Brooke 2004). The foraging niche of seabirds is influenced by a range of factors, including environmental conditions (Waugh \& Weimerskirch 2003, Amélineau et al. 2016, Jakubas et al. 2017), prey availability (Baird 1991, Camprasse et al. 2017), morphological characteristics and their influence on flight performance (Phillips et al. 2004, 2005, Navarro et al. 2013), and interspecific competition (González-Solís et al. 2008, Phillips et al. 2008, Kokubun et al. 2016). Competition is thought to promote foraging niche divergence since species occupying the same ecological niche cannot theoretically coexist through time (Schoener 1974). Seabirds may separate their resources on several dimensions, with studies showing divergence in foraging zone (González-Solís et al. 2008, Barger et al. 2016), diving depth (Mori \& Boyd 2004), the timing of breeding (Granroth-Wilding \& Phillips 2019), and seasonal patterns of activity (Phillips et al. 2008). In particular, divergence in diet has been proposed as an important mechanism in reducing niche overlap (Ridoux 1994, Surman \& Wooller 2003, Pratte et al. 2017).

Bass Strait, the shallow continental shelf area between mainland Australia and Tasmania (Fig. 1), is a key region for Australian seabirds, supporting a large proportion of breeding populations of at least 11 major species (Table 1; Ross et al. 2001). This area is considered a region of low primary productivity (Gibbs et al. 1986, Gibbs et al. 1991) that occurs at the confluence of three main ocean currents. The warm, oligotrophic waters of the East Australian Current (EAC) flow southward along the eastern edge of Bass Strait (Ridgeway \& Godfrey 1997, Sandery \& Kämpf 2007) while the South Australian Current (SAC) advects warm water from the west onto the shelf which then flows eastward through Bass Strait (Sandery \& Kämpf 2007). The latter is the 
55

56

57

58

59

60

61

62

63

64

65

66

67

68

major source of Bass Strait water and is strongest in winter (Ridgeway \& Condie 2004, Sandery

\& Kämpf 2007). In summer, a weakening or reversal of this eastward-flowing trend occurs

(Gibbs et al. 1986, Sandery \& Kämpf 2007). Finally, in winter, cold, nutrient-rich sub-Antarctic surface water (SASW) enters Bass Strait from the south (Gibbs 1992) where it mixes with the EAC and SAC along the sub-Tropical Convergence (STC, Prince 2001).

The relative influence of the currents and upwelling systems affecting Bass Strait varies spatially, seasonally and inter-annually (Prince 2001, Sandery \& Kämpf 2005). This affects the reproductive success of seabirds in Bass Strait, presumably due to shifts in prey availability (Mickelson et al. 1992). Additionally, climate change is predicted to weaken the SAC (Feng et al. 2012) and increase the strength of the EAC, resulting in warming along the path of its strengthening (Cai et al. 2005). This is likely to have a considerable impact on the marine ecosystem of Bass Strait. Seabird assemblages in other parts of the world have shown differential responses to shifts in ocean regimes in parameters such as breeding success, population size and survivorship due, at least in part, to changes in prey availability (Croxall et al. 2002). Knowledge of the trophic relationships and diets of Bass Strait seabirds is crucial for predicting their population responses to environmental change. This information is important for the conservation of these marine predators and for the refinement of sustainable fisheries management practices. At present, the trophic structure of Bass Strait seabird community is poorly understood, with trophic niches of most pelagic species not yet described or based on a few localised studies that did not address spatial or temporal variation. Accordingly, it is not known whether, or how, they diverge in foraging niche.

6 The little penguin Eudyptula minor, short-tailed shearwater Ardenna tenuirostris, fairy prion Pachyptila turtur and common diving petrel Pelecanoides urinatrix are the most abundant and 
78 ubiquitous seabirds in Bass Strait, breeding sympatrically on numerous offshore islands

79 (Schumann et al. 2014). They are known to feed on a variety of fish, cephalopod and/or

80

81

82

83

84

85 crustacean prey (Harper 1976, Montague et al. 1986, Schumann et al. 2008, Chiaradia et al. 2010). Previous foraging ecology studies indicate that the little penguin is an inshore forager relying mainly on small pelagic schooling fish (Cullen et al. 1992, Chiaradia et al. 2010), while the pelagic short-tailed shearwater, with a foraging range extending to the Antarctic waters (Woehler et al. 2006, Cleeland et al. 2014), and the smaller and more neritic fairy prion and common diving petrel, feed on a wide range of small prey, concentrating predominantly on coastal krill (Nyctiphanes australis) and myctophid fish (Harper 1976, Weimerskirch \& Cherel 1998, Schumann et al. 2008). However, in Bass Strait, information on spatial and temporal variation in the ecology of these species is limited to the at-sea foraging behaviour of little penguins and short-tailed shearwaters (e.g. Collins et al. 1999, Chiaradia et al. 2010, Berlincourt \& Arnould 2015a,b) and there is almost no information on the small procellariforms (Underwood 2012).

The aims of the present study, therefore, were to: 1) determine the trophic niche of the study seabirds using both stomach contents and stable isotope analysis; 2) investigate temporal (interannual and seasonal) and geographic variation in their isotopic niche, and 3) assess the degree of niche segregation between these four abundant species within Bass Strait.

\section{MATERIAL \& METHODS}

8 The study was conducted during the winters (July - August) of 2008 - 2010 and summers

99 (January - February) of 2009- 2011 in three regions of Bass Strait, south-eastern Australia (Fig. 
100 1). In summer, the study species were sampled in mid, early and late chick-rearing, respectively

101 for the little penguin (Reilly \& Cullen 1981), the short-tailed shearwater (Vertigan 2010) and the

102 fairy prion (Harper 1976) (Fig. 2). In winter, sampling occurred during the inter-breeding period

103 for the little penguin (Reilly \& Cullen 1981) and fairy prion (Harper 1976) and incubation for the

104 common diving petrel (Schumann et al. 2008) (Fig. 2). The trophic niches of little penguins,

105 short-tailed shearwaters, fairy prions and common diving petrels were determined using two

106 complementary techniques. Trophic information was derived from stable isotope values in whole

107 blood of each species in western, central and eastern Bass Strait, and stomach samples were

108 collected from the seabirds in central Bass Strait to assess the relative importance of prey and

109 inform interpretation of the stable isotope results. Procellariiform study species were banded and

110 little penguins were micro-chipped to avoid sampling the same individual more than once. All

111 research was conducted under permit from Deakin University (animal ethic permit: AWC A9-

112 2008) and the Department of Sustainability and Environment (Permit No. 10004530), and access

113 to the islands was provided by Parks Victoria.

\section{Dietary analysis}

116 Stomach contents analysis provides information on the composition and abundance of prey

117 consumed (Duffy \& Jackson 1986). Stomach samples were collected from the four seabird

118 species on Notch ( $\left.38^{\circ} 56^{\prime} \mathrm{S}, 146^{\circ} 37^{\prime} \mathrm{E}\right)$ and Kanowna (39 $\left.10^{\circ} \mathrm{S}, 148^{\circ} 16^{\prime} \mathrm{E}\right)$ Islands in central Bass

119 Strait (Fig. 1). Adult little penguins were sampled in both winter and summer (n=20 and 22,

120 respectively), short-tailed shearwater and fairy prion diet samples were collected in summer only

121 ( $n=51$ and 20, respectively) and common diving petrels were sampled in winter only $(n=6)$ 
122 (Fig. 2). Due to logistical constraints and few individuals onshore in some years, it was not 123 possible to sample all species in all years.

124 Adult birds were captured as they came ashore at night after foraging at sea. Diet samples were 125 collected using the water-offloading technique. While it is possible that not all stomach contents 126 were retrieved, stomach flushing is an effective technique for diet estimation in seabirds (Gales 127 1987) and, in most cases, the majority of prey remains were ejected on the second (final) flush, 128 as evidenced by clear water being ejected. After flushing, birds were given an electrolyte 129 solution of Vytrate or Lectade (Jurox Pty Ltd, NSW), and placed into boxes for recovery 130 (Chiaradia et al. 2003). Little penguins and short-tailed shearwaters were also provided with a 131 meal, delivered via a stomach tube, of homogenised pilchard (purchased snap-frozen and 132 unsalted) immediately before release.

133 Diet samples were frozen $\left(-20^{\circ} \mathrm{C}\right)$ or stored in $70 \%$ ethanol after collection. Crustacean remains 134 were initially identified to lower taxonomic levels with reference to Ritz et al. (2003). Sagittal 135 otoliths, scales, fish mouth parts and cephalopod beaks were identified by comparison to 136 reference atlases (Neira et al. 1998, Lu \& Ickeringill 2002, Furlani et al. 2007) and collections 137 (held by Phillip Island Nature Parks and Deakin University).

138 Fresh prey items were washed with water and separated from accumulated ones. To estimate the numerical abundance of crustacean prey, the heads of amphipods and whole bodies of copepods, isopods and crab megalopa were counted directly while individual eyes of krill and stomatopods were counted and divided by two. Left and right otoliths were counted and the side comprising

142 the greater number considered representative of the minimum number of each fish taxon per sample. Where otoliths were unidentifiable, their abundance was halved and rounded to the nearest number. Similarly, the highest number of upper or lower squid beaks in a sample was 
145 used to estimate the abundance of cephalopods and only unbroken beaks were measured to

146 estimate size (Tollit et al. 1997). Hard prey remains that could not be quantified, such as fish

147 scales, were assigned a numerical abundance of one. The frequency of occurrence of prey

148 remains was calculated as the proportion of samples containing identifiable remains in which a

149 particular prey type occurred while the numerical abundance was expressed as the mean number

150 of each prey taxon encountered in samples.

\section{Stable isotope analyses}

153 Stable carbon $\left(\delta^{13} \mathrm{C}\right)$ and nitrogen $\left(\delta^{15} \mathrm{~N}\right)$ values in tissues have been used to infer the diet of a 154 range of marine species (Hobson \& Welch 1992, Hobson 1993, Cherel et al. 2007). Stable 155 isotope values of $\delta^{13} \mathrm{C}$ values allow discrimination between benthic and pelagic prey (e.g., Cherel 156 et al. 2007) and inshore and offshore feeding (Hobson et al. 1994b), while $\delta^{15} \mathrm{~N}$ in tissues show

157 enrichment with increasing trophic levels (Hobson et al. 1994a). Information derived from whole 158 blood, as used in the present study, reflects dietary integration of approximately four weeks 159 (Bearhop et al. 2002).

160

161

162

163

164

165

166

Blood samples $(<0.2 \mathrm{ml})$ were collected from seabirds resident in western (WBS - Lady Julia Percy Island: $\left.38^{\circ} 25^{\prime} \mathrm{S}, 142^{\circ} 00^{\prime} \mathrm{E}\right)$, central (CBS - Notch, Kanowna, Norman: $39^{\circ} 02^{\prime} \mathrm{S}, 1^{\circ} 6^{\circ} 12^{\prime} \mathrm{E}$ and Anser Islands: $\left.39^{\circ} 09^{\prime} \mathrm{S}, 1^{\circ} 6^{\circ} 18^{\prime} \mathrm{E}\right)$ and eastern Bass Strait (EBS - Gabo Island: 37³4’S, $\left.149^{\circ} 55^{\prime} \mathrm{E}\right)$. A total of 278 (167 in summer, 111 in winter), 177 (summer only), 88 (66 in summer, 22 in winter) and 38 (winter only) stable isotope profiles were obtained from little penguins, short-tailed shearwaters, fairy prions and common diving petrels, respectively. Adult individuals (only birds that were not sampled for diet determination) were captured as they 
167 returned to their nesting burrows at night or taken from their burrows during the day. Little

168 penguins and short-tailed shearwaters were captured by hand, common diving-petrels were

169 captured in mist nets, and fairy prions were captured by hand or using hand nets as they

170 approached their burrows. Upon capture, blood was collected into a heparinised syringe via

171 venipuncture of the tarsal vein or an inter-digital vein in the foot.

172 Blood samples were stored frozen $\left(-20^{\circ} \mathrm{C}\right)$ and, prior to analysis, oven dried $\left(60^{\circ} \mathrm{C}\right)$ and

173 homogenised using a mortar and pestle. The low lipid content of whole blood does not typically

174 necessitate lipid extraction (Cherel et al. 2005a). Indeed, all mean values of C:N mass ratio

175 encompassed a narrow range (3.1-3.7) indicating low lipid content and, thus, allowing accurate

176 comparisons of $\delta^{13} \mathrm{C}$ values among groups (Bond \& Jones 2009). Isotope ratios in whole blood

177 were measured using a continuous-flow isotope ratio mass spectrometer, with analyses

178 conducted by the Isotope Ratio Mass Spectrometry service in the Research School of Biology,

179 Australian National University (Canberra, Australia). The values of stable isotope abundances

180 were expressed in $\delta$-notation as the deviation from standards in parts per thousand according to

181 the equation:

182

183

$\delta X=\left[\left(R_{\text {sample }} / R_{\text {standard }}\right)-1\right]$

where $X$ is ${ }^{15} \mathrm{~N}$ or ${ }^{13} \mathrm{C}$ and $R$ represents the corresponding ${ }^{15} \mathrm{~N} /{ }^{14} \mathrm{~N}$ or ${ }^{13} \mathrm{C} /{ }^{12} \mathrm{C}$ ratios (Hobson et al. 1994a). $R_{\text {standard }}$ values were based on Vienna Pee Dee Belemnite for ${ }^{13} \mathrm{C}$, and atmospheric

188 error was estimated to be \pm 0.20 and $\pm 0.15 \%$ for $\delta^{15} \mathrm{~N}$ and $\delta^{13} \mathrm{C}$, respectively. 


\section{Statistical analyses}

191 All statistical analyses were conducted in the R statistical environment 3.5.1 (R Core Team

192 2018). To investigate the effect of geographic, inter-annual and seasonal variations in stable

193 isotope values, generalised linear models (GLM) were fitted using the lme4 package (Bates et al.

194 2014). Terms were added sequentially, model selection was based on Akaike's information

195 criterion (AIC), and the global models were checked to ensure normality and homoscedasticity

196 of the residuals. Post-hoc tests were conducted using analyses of variance (ANOVA) and $t$-tests,

197 or Kruskal-Wallis and Wilcoxon rank sum tests where transformations did not improve data

198 distributions. The stable isotope Bayesian ellipses in R (SIBER package; Jackson et al. 2011)

199 were used to determine the isotopic niche width of each species in each region, for each year and

200 season. The Standard Ellipse Area corrected $\left(\mathrm{SEA}_{\mathrm{C}} ; 40 \%\right.$ probability of containing a

201 subsequently sampled datum regardless of sample size) was used to quantify niche width. The

202 Bayesian estimate of the standard ellipse and its area $\left(\mathrm{SEA}_{\mathrm{B}}\right)$ were used to measure the overlap

203 of the isotopic niches between groups (Jackson et al. 2011). The niche overlap was estimated as

204 the isotopic area of overlap from the maximum likelihood fitted ellipses of two given groups.

205

206 RESULTS

207 Diet

208 Stomach content samples were obtained from individuals between August 2008 and January

2092011 in order to inform interpretation of the stable isotope results. Samples were collected from

210 little penguins in both winter and summer (2008-2009), from short-tailed shearwaters in summer 
2112009 and 2010, from fairy prions in summer 2011 and from common diving petrels in winter

2122008 and 2009. Overall, 79, 84, 95 and $40 \%$ of little penguin, short-tailed shearwater, fairy prion

213 and common diving-petrel samples, respectively, contained identifiable fresh prey remains.

214 Stomach samples of studied seabird species contained remains of fish, cephalopods and

215 crustaceans (Table 2). Not all taxa could be identified to species level. Little penguins ingested

216 crustaceans, comprising isopods, amphipods and/or copepods, but consumed mainly jack

217 mackerel in winter and Australian anchovy Engraulis australis in summer, though high numbers

218 of post-larval fish were also ingested in summer (Table S1 in the Supplement). The diets of all

219 three procellariform species were dominated by euphausiids, particularly coastal krill

220 (Nyctiphanes australis), representing $78-96 \%$ of the mean number of prey items consumed by

221 these species (Table S2 and Table S3 in the Supplement). Other important prey taxa included

222 Euphausia sp. and the hyperiid amphipod Themisto australis for short-tailed shearwaters, the

223 megalopa stage of a swimming crab species Ovalipes sp. for fairy prions and hyperiid amphipods

224 for common diving-petrels. For short-tailed shearwaters, the abundance of crustaceans was

225 higher in 2010 than in 2009 (Wilcoxon-test, $w=126.5$, $p$-value $<0.01$ ), mainly driven by the

226 variation in number per samples of coastal krill $(n=118.9 \pm 52.6$ and $n=969.6 \pm 194.2$ in 2009

227 and 2010, respectively).

Stable isotopes analysis

230 Blood samples were collected from all four species in WBS and CBS, and from little penguins 231 and short-tailed shearwaters in EBS (Table 3 and 4). Values of $\delta^{13} \mathrm{C}$ ranged between -20.6 and -

$23218.1 \%$ o for little penguins, between -23.7 and $-20.4 \%$ for short-tailed shearwaters, between - 
23321.0 and $-18.3 \%$ for fairy prions and between -21.4 and $-19.4 \%$ for common diving petrels.

234 Whole blood $\delta^{15} \mathrm{~N}$ values ranged between 10.8 and $16.0 \%$ for little penguins, between 7.8 and

$23511.4 \%$ for short-tailed shearwaters, between 8.8 and $14.8 \%$ for fairy prions and between 10.9

236 and $14.5 \%$ for common diving petrels (Fig. S1 in the Supplement).

237 For all four species, stable isotope values in whole blood showed intraspecific variation between

238 regions and years (Fig. 3 and 4). Inter-annual variations of $\delta^{13} \mathrm{C}$ values were significant in all

239 species in most regions (Paired $t$-test or Wilcoxon-test: $P<0.01$ ) except for short-tailed

240 shearwater and common diving petrel in CBS ( $t$-test: $P>0.07)$. While there was no pattern in

$241 \delta^{13} \mathrm{C}$ differences between regions for the short-tailed shearwater, for the three other species

242 values in CBS were generally lower than those from WBS (0.56 \%o to $1.40 \%$ lower) (Tables 3

243 and 4). Indeed, for the little penguin, fairy prion and common diving petrel, the variable "region"

244 explained, respectively, 43, 37 and $58 \%$ of the variance for the $\delta^{13} \mathrm{C}$ model, but only $2 \%$ for the

245 short-tailed shearwater. For $\delta^{15} \mathrm{~N}$, the best models retained, with interactions, the $\delta^{13} \mathrm{C}$, the region

246 and the year (and season for the little penguin and fairy prion) as significant variables explaining

$24760 \%$ to $93 \%$ of the deviance (Table S4 in the Supplement). While "season" explained 27.1\% of

248 the model for the fairy prion (winter data available only for WBS in 2009), this variable was not

249 significant for the little penguin (accounting for only $0.2 \%$ of the variation). No inter-seasonal

250 variations of $\delta^{13} \mathrm{C}$ in blood of little penguin and fairy prion were found (except in CBS, paired $t$ -

251 test or Wilcoxon-test: $P<0.01)$. Significant inter-annual differences were recorded in all regions

252 (Paired $t$-test or Wilcoxon-test: $P<0.01$ ), but no clear pattern was detected in the values or the

253 isotopic niche metrics (Tables 3, 4 and Table S5 in the Supplement). Similarly, for each year, the

$254 \delta^{15} \mathrm{~N}$ values varied between region for the little penguin, fairy prion and common diving petrel

255 (Paired $t$-test or Wilcoxon-test: $P<0.01$ ). For the short-tailed shearwater, a spatial difference in 
$256 \delta^{15} \mathrm{~N}$ values was detected between WBS and EBS in 2010 (Paired $t$-test $t_{37}=-2.19, P<0.05$ ), but

257 no other differences were found. The models for $\delta^{13} \mathrm{C}$ retained the region and year as main

258 variables for all the study species, explaining $55 \%$ to $70 \%$ of the variance (Table S4 in the

259 Supplement).

260 The four study species occupied different isotopic niches in all years and each region (Fig. S1 in

261 the Supplement). Values of $\delta^{13} \mathrm{C}$ and $\delta^{15} \mathrm{~N}$ in whole blood of short-tailed shearwaters were lower

262 (with no isotopic niche overlap) than those of the other species in each region in all three years

263 (paired t-test or Wilcoxon-test: $\mathrm{p}<0.01$, Table 3 and Table S5 in the Supplement). In contrast,

264 mean $\delta^{15} \mathrm{~N}$ values in blood of little penguins typically showed the greatest enrichment in both

265 winter and summer, though this varied spatially and inter-annually (Table 3 and 4). Isotopic $\delta^{13} \mathrm{C}$

266 values of little penguins and fairy prions were relatively similar, but tended to be higher than

267 those of common diving-petrels in winter, particularly in CBS. While the isotopic niche of the

268 fairy prion overlapped sparsely with the common diving petrel $\left(\mathrm{SEA}_{\mathrm{B}}\right.$ overlap $\left.<8.1 \%\right)$, and with

269 little penguin in 2009 and $2011\left(\mathrm{SEA}_{\mathrm{B}}\right.$ overlap $\left.<4.9 \%\right)$, niche overlap with the little penguin was

270 important in 2010 (maximum $\mathrm{SEA}_{\mathrm{B}}$ overlap $=21.8 \%$ in winter 2010 in WBS, Table $\mathrm{S} 5$ in the

271 Supplement).

272

\section{DISCUSSION}

274 Foraging niches of sympatric seabird species diverge in a variety of spatial and temporal ways

275 (Waugh \& Weimerskirch 2003, González-Solís et al. 2008, Davies et al. 2009). Bass Strait is

276 occupied by an abundant marine avifauna (Ross et al. 2001), with little previously known of the

277 trophic niches of most species. Combining stomach contents and stable isotope analyses, the 
278 present study has shown that the four most abundant and ubiquitous species generally occupy

279 different trophic niches that vary among regions, years and season.

\section{Diet}

282 The little penguin is considered an inshore generalist forager relying mostly on small pelagic prey such as Clupeiformes (Cullen et al. 1992, Chiaradia et al. 2010, Sutton et al. 2015). In the present study, stomach contents of little penguins in summer were similar to that previously reported, with Australian anchovy and post-larval fish contributing the majority of samples. In contrast, winter stomach contents were dominated by jack mackerel, highlighting a seasonal switch in the availability of the main prey of little penguins. Such differences have also been shown in little penguins from Albatross Island in southern Bass Strait (Gales \& Pemberton 1990) and Phillip Island in northern Bass Strait (Cavallo et al. 2018). While recent studies have observed that jellyfish can contribute a substantial proportion of the little penguin diet (Sutton et al. 2015, Cavallo et al. 2018), no evidence of such prey were found in the present study. This could potentially be due to rapid digestion of gelatinous prey in comparison to fish or crustaceans (Cavallo et al. 2018), emphasising the limitation of traditional stomach content analyses, or reflect inter-annual differences in available prey types.

Stomach contents of short-tailed shearwaters in the present study were similar to those of individuals from Tasmania (Weimerskirch \& Cherel 1998, Cherel et al. 2005b). The main identified prey was the coastal krill, indicating that sampled birds were mostly returning from short foraging trips over the continental shelf (Blackburn 1980, Weimerskirch \& Cherel 1998). Indeed, during the breeding season, short-tailed shearwaters alternate between short (1-2 d) local trips within 35-70 km of the colony and long trips (10-20 d) to Antarctic waters (Weimerskirch 
301 \& Cherel 1998, Woehler et al. 2006, Raymond et al. 2010, Einoder et al. 2011, Berlincourt \&

302 Arnould 2015b) where they feed mainly on coastal krill, and myctophid fish and Antarctic krill,

303 respectively (Montague 1986, Weimerskirch \& Cherel 1998). In the 2010 samples, a limited

304 number of birds $(\mathrm{n}=4)$ had stomach contents dominated by stomach oil and digested Euphausia

305 sp, suggesting they had returned from long trips to Antarctic waters (Weimerskirch \& Cherel 306 1998).

307 Coastal krill occurs in neritic waters of eastern Australia, where other krill species are rare or 308 absent (Blackburn 1980). Due to its abundance, it plays a key role in the coastal ecosystem, 309 reflected by its dominance in the diets of various cetacean, seabirds and fish species (O'Brien 310 1988, Gill et al. 2011, Woehler et al. 2014). Despite limited data on the diet of fairy prions and 311 common diving petrels in Bass Strait, their stomach contents confirmed the importance of coastal 312 krill to these species in the Australasian region (Harper 1976, Schumann et al. 2008). These 313 results, together with estimates of trip duration in previous studies (1-3 d trips at sea, Harper 314 1976, Bocher et al. 2000a, b, Navarro et al. 2013, Zhang et al. 2018), suggest that both breeding 315 fairy prions and common diving petrels most likely forage within Bass Strait or in the vicinity of 316 the continental shelf. This analysis emphasises the value of a multi-tools approach when 317 considering niche segregation, as here, while stomach analysis can suggest substantial dietary 318 overlap among the procellariiforms, isotopic and tracking analysis may be able to tease the 319 species apart into separate foraging niches.

Spatial variability in isotopic niche

322 Since whole blood integrates dietary information over approximately four weeks (Bearhop et al. 323 2002), it might be expected that isotopic values for short-tailed shearwaters would reflect a 
324 combination of both their local and Antarctic foraging areas (Berlincourt \& Arnould 2015b),

325 thereby masking any differences in blood isotope values between foraging zones. However,

326 Cherel et al. (2005b) showed that while most of the food consumed by short-tailed shearwaters

327 during short local trips is allocated to their chick, adults feed for themselves when foraging

328 farther south and, therefore, have a truly Antarctic blood isotopic signature. In the present study,

329 values of $\delta^{13} \mathrm{C}$ in whole blood of short-tailed shearwaters were comparable to those of other

330 procellariforms foraging in subantarctic waters (Cherel et al. 2002a, Cherel et al. 2002b,

331 Quillfeldt et al. 2005) but were slightly higher than those in plasma of short-tailed shearwaters

332 from south Tasmania (Cherel et al. 2005b).

333 Interestingly, the $\delta^{13} \mathrm{C}$ values of short-tailed shearwaters varied significantly between the three

334 study regions in Bass Strait, indicating possible foraging spatial segregation within the Southern

335 Ocean by individuals from the different regions. As $\delta^{13} \mathrm{C}$ values are higher in subtropical than in

336 Antarctic waters (Cherel \& Hobson 2007, Cherel et al. 2007, 2010, Jaeger et al. 2010), this

337 suggests a latitudinal segregation in the foraging areas between the three sampled populations.

338 However, this variation was not consistent across years, with strong inter-annual variability in

$339 \delta^{13} \mathrm{C}$ values for birds from WBS and EBS compared to CBS. This could suggest not only colony-

340 specific niche segregation but also density-dependent competition (Ainley et al. 2004, Wakefield

341 et al. 2013), with the smallest colonies having a more flexible foraging area. Indeed, the CBS

342 population is considerably bigger than the WBS and EBS populations, with $755,400,30,000$ and

3436,000 breeding pairs, respectively (Bowker 1980, Pescott 1976, Fullagar \& Heyligers 1996,

344 Schumann et al. 2014). This is in accordance with previous tracking studies (Berlincourt \&

345 Arnould 2015b) that observed inter-annual longitudinal and latitudinal variation in the long trip

346 foraging areas of short-tailed shearwater from the small populations in WBS and EBS. Despite 
347 the geographic and temporal differences in $\delta^{13} \mathrm{C}$ observed, there were no major differences in the

$348 \delta^{15} \mathrm{~N}$ values between regions in the present study, highlighting the consistency of the diet of

349 short-tailed shearwaters in the Southern Ocean.

350 For little penguins, fairy prions and common diving petrels, seasonal and geographic differences

351 in isotopic signatures are likely to reflect differences in prey availability associated with the

352 strength of the prevailing of ocean currents and upwelling systems in the different regions of

353 Bass Strait. For example, the SAC may transport cold waters from the west into Bass Strait

354 (Mickelson et al. 1992, Sandery \& Kämpf 2007), weakening towards the east (Sandery \& Kämpf

355 2007) where the EAC increases in prevalence, bringing warmer nutrient-poor water into north-

356 eastern Bass Strait (Gibbs 1992). This was reflected in $\delta^{13} \mathrm{C}$ values in the whole blood of little

357 penguins and fairy prions, where values were systematically lower in CBS than in WBS and

358 EBS. Similar observations have been reported for Australian fur seals where $\delta^{13} \mathrm{C}$ values in blood

359 plasma of individuals from CBS were consistently lower than those from EBS (Arnould et al.

360 2011). In winter, however, spatial differences in isotopic values declined. This may reflect the

361 homogenization of Bass Strait waters in winter due to a greater influence of the SAC and SASW

362 during this period (Prince 2001, Sandery \& Kämpf 2007).

\section{Inter-annual trophic variability}

365 The isotope values in the whole blood of little penguins from WBS and CBS in summer are within the range previously reported from Phillip Island in CBS (Chiaradia et al. 2010, Chiaradia et al. 2012), with the exception of 2010 when $\delta^{15} \mathrm{~N}$ values were significantly lower in both regions. This could reflect fluctuations in isotopic baseline signatures due to different water masses and variable strength of the currents influencing the regions where individuals foraged. 
370 Indeed, as reported by Polito et al. (2019), variations in oceanic factors such as chlorophyll- $a$

371 concentration can substantially alter mean isotope values independently of any change in the diet

372 of the species. However, inter-annual variation in $\delta^{15} \mathrm{~N}$ values could also reflect a variation in

373 main prey species consumed, with little penguins known to have important inter-annual

374 variability in their diet (Gales \& Pemberton 1990, Cullen et al. 1992, Chiaradia et al. 2010). In

375 the present study, individuals from CBS in summer 2009 consumed predominantly Australian

376 anchovy, a species exploiting higher trophic levels than other prey targeted by little penguins

377 (Espinoza et al. 2009, van der Lingen et al. 2009). As previously highlighted by Chiaradia et al.

378 (2010), $\delta^{15} \mathrm{~N}$ values are higher during years with an important proportion of anchovy in little

379 penguin diet. Therefore, it is likely that the low $\delta^{15} \mathrm{~N}$ values in summer 2010 in the present study

380 was due to a depletion of Australian anchovy in the diet, potentially due to a reduced availability

381 in the region. This is consistent with previous reports indicating inter-annual flexibility in little

382 penguin at-sea foraging behaviour in relation to environmental conditions that directly influence

383 prey abundance (Berlincourt \& Arnould 2015a, Camprasse et al. 2017). Indeed, in WBS and

384 CBS, the niche space occupied by little penguins in 2010 was much larger than in 2009 and

385 2011, indicating a larger trophic diversity (Layman et al. 2007), possibly due to the absence of

386 the usual main prey. Similarly, for both fairy prions and common diving petrels, $\delta^{15} \mathrm{~N}$ values in

387 the whole blood of both species in the region varied substantially between years, suggesting a

388 potential variation in the importance of their main prey (coastal krill) in their respective diet.

389 Significant inter-annual differences in the density and biomass of coastal krill in southern Bass

390 Strait have previously been observed (Young et al. 1993). 
393 In the present study, interspecific comparisons of stomach contents and $\delta^{15} \mathrm{~N}$ values revealed that

394 little penguins typically occupied the highest trophic positions of the four seabird species while

395 short-tailed shearwaters always occupied the lowest. Little penguin $\delta^{15} \mathrm{~N}$ values were

396 nevertheless lower than those of the top predators shy albatross and Australian fur seal (Arnould

397 et al. 2011; Cherel et al. 2013), but were close to the values of the large Australasian gannet

398 (Angel et al. 2016), that predominantly consumes pilchards and anchovy (Bunce 2001) (Fig. 5).

399 In contrast, $\delta^{15} \mathrm{~N}$ values of short-tailed shearwaters, fairy prions and common diving petrels were

400 remarkably lower than those of the much smaller white-faced storm petrels (Underwood 2012)

401 (Fig. 5), which consume a significant proportion of fish in addition to coastal krill (Underwood

402 2012). These results, combined with the stomach content analysis, confirm that coastal krill was

403 a key prey taxon in all three procellariforms in central Bass Strait. During breeding, both fairy

404 prions and common diving petrels return to the nest every night (Harper 1976, Payne \& Prince

405 1979), suggesting that they forage mainly on the shelf near their colonies. Elsewhere, fairy

406 prions take prey from the surface waters (Harper 1987, Prince \& Morgan 1987) whereas

407 common diving petrels exploit depths averaging 2-4m (Navarro et al. 2013, Navarro et al. 2014,

408 Dunphy et al. 2015). Likewise, despite isotopic signatures showing self-maintenance feeding in

409 the Southern Ocean, short-tailed shearwaters forage on coastal krill over the shelf near colonies

410 during short trips (Einoder et al. 2011, Berlincourt \& Arnould 2015b), resulting in the potential

411 for interspecific overlap in the foraging zones of the three procellariforms. However, short-tailed

412 shearwaters forage at deeper depths (average $13 \mathrm{~m}$ ) during local trips (Weimerskirch \& Cherel

413 1998). While the foraging zones and dive depths of little penguins may overlap with those of

414 short-tailed shearwaters (Berlincourt \& Arnould 2015a, 2015b), the limited distance travelled per

415 trip and fish-based diet of little penguins would reduce competition with procellariforms. 
416 In addition to segregation of diet and foraging behaviour, the four species differ in their breeding

417 phenologies. Common diving petrels, fairy prions and short-tailed shearwaters lay their eggs in

418 late July, late October and late November, respectively (Harris 1979, Marchant \& Higgins 1990).

419 Thus, there is limited overlap in the breeding periods of the three procellariforms. However, the

420 protracted and variable breeding season of little penguins (Reilly \& Cullen 1981, Cullen et al.

421 1992) may overlap with the other species. Interspecific competition may, therefore, intensify in

422 years of low fish prey availability. Indeed, previous studies have documented the presence of

423 coastal krill in the diet of little penguin during years of low prey availability (Cullen et al. 1992).

424 The dependence of these seabird species on relatively few prey types (such as coastal krill,

425 pilchard or anchovy) may increase the impacts of reductions in prey abundance. Climate models

426 have described an intensification of the EAC due to large-scale changes in ocean circulation in

427 the Southern Hemisphere (Cai 2006), produced in association with an increasing trend in the

428 Southern Annular Mode (Cai et al. 2005). During years of intensified EAC, Young et al. (1993)

429 reported a dramatic drop in coastal krill biomass. This is likely to adversely affect seabirds in the

430 region (Mills et al. 2008, Chambers et al. 2011). Similarly, significant mortality events, poor

431 chick growth and population declines in short-tailed shearwaters in Tasmania have been

432 previously attributed to local prey shortages (Vertigan 2010). Declines in coastal krill availability

433 may also indirectly impact little penguins since this species is an important dietary component of

434 several of their prey taxa (Harris et al. 1979, O’Brien 1988). The predicted increase in the

435 strength of the EAC with climate change (Cai et al. 2005) could, therefore, have severe negative

436 consequences for the Bass Strait seabird community (Chambers et al. 2011). 
439 In summary, the present study has shown that the isotopic niches of seabirds in Bass Strait vary

440 significantly between regions, years and seasons. These differences are likely to result from

441 changes in prey availability driven by variations in ocean currents and local productivity. Despite

442 interspecific similarities in diet, divergence in the relative foraging niche is likely to reduce

443 interspecific competition for prey, though this may become more important in years of low prey

444 availability. The low diversity of prey taxa ingested by these seabirds suggests that they are

445 vulnerable to changes in the availability of key prey. In order to better understand the foraging

446 niches of the Bass Strait community of seabirds, as well as their capacity to adapt to changing

447 environmental conditions, more detailed information on their foraging zones and feeding

448 behaviour is required. This is particularly important for the small procellariforms in light of the

449 paucity of information in south-eastern Australia, in contrast to the numerous studies that have

450 been conducted on little penguins and short-tailed shearwaters in the region (e.g. Ropert-Coudert

451 et al. 2004, 2009, Cleeland et al. 2014, Berlincourt \& Arnould 2015a, b). Such information may

452 help elucidate the likelihood of interspecific competition in this assemblage of seabirds.

\section{ACKNOWLEDGEMENTS}

455 The contribution of Dr Roger Kirkwood and Dr Michael Lynch who collected blood samples

456 from Lady Julia Percy Island during some seasons, and Dr Tom Montague who provided

457 information on identification of fish prey remains using mouth parts and scales is gratefully

458 acknowledged. We thank Dr Alice Carravieri who provided useful comments on the later version

459 of the manuscript, and Dr Tim Poupart and Dr Paul Tixier for their respective help on statistical

460 analysis and $\mathrm{R}$ code. 


\section{REFERENCES}

463

464

465

466

467

468

469

470

471

472

473

474

475

476

477

478

479

480

481

Ainley DG, Ribic CA, Ballard G, Heath S, Gaffney I, Karl BJ, Barton KJ, Wilson PR, Webb S (2004) Geographic structure of Adelie penguin populations: overlap in colony-specific foraging areas. Ecol Mono 74(1):159-178

Alderman RL, Gales R, Tuck GN, Lebreton JD (2011) Global population status of shy albatross and an assessment of colony-specific trends and drivers. Wildl Res 38: 672-686

Amélineau F, Grémillet D, Bonnet D Bot TL, Fort J (2016) Where to forage in absence of sea ice? Bathymetry as a key factor for an Arctic seabird. PLOSE ONE 11:e0157764

Angel LP, Berlincourt M, Arnould JPY (2016) Pronouced inter-colony variation in the foraging ecology of Australian gannets: influence of habitat differences. Mar Ecol Prog Ser $556: 261-272$

Arnould JPY, Cherel Y, Gibbens J, White JG, Littnan CL (2011) Stable isotopes reveal interannual and inter-individual variation in the diet of female Australian fur seals. Mar Ecol Prog Ser 422:291-302

Baird PH (1991) Optimal foraging and intraspecific competition in the tufted puffin. Condor 93:503-515

Barger CP, Young RC, Cable JM, Ito M, Kitaysky AS (2016) Resource partitioning between sympatric seabird species increases during chick-rearing. Ecosphere 9:e01447

Bates D, Maechler M, Bolker B, Walker S (2014) lme4: Linear mixed-effects models using Eigen and S4. R package version 1.1-6. http://CRAN.R-project.org/package=lme4 
482 Bearhop S, Waldron S, Votier SC, Furness RW (2002) Factors that influence assimilation rates

483

484

485

486

487

488

489

490

491

492

493

494

495

496

497

498

499

500

501

and fractionation of nitrogen and carbon stable isotopes in avian blood and feathers. Physiol Biochem Zool 75:451-458

Berlincourt M, Arnould JPY (2015a) Influence of environmental conditions on foraging behaviour and its consequences on reproductive performance in little penguins. Mar Biol $162: 1485-1501$

Berlincourt M, Arnould JPY (2015b) Breeding short-tailed shearwaters buffer local environmental variability in south-eastern Australia by foraging in Antarctic waters. Mov Ecol 3:16

Blackburn M (1980) Observations on the distribution of Nyctiphanes australis Sars (Crustacea, Euphausiidae) in Australian waters. Rep Div Fish Oceanogr CSIRO 119:1-10

Bocher P, Cherel Y, Hobson KA (2000a) Complete trophic segregation between south georgian and common diving petrels during breeding at Iles Kerguelen. Mar Ecol Prog Ser 208:249-264

Bocher P, Labidoire B, Cherel Y (2000b) Maximum dive depths of common diving petrels (Pelecanoides urinatrix) during the annual cycle at Mayes Island, Kerguelen. J Zool Lond 251:517-524

Bond AL, Jones IL (2009) A practical introduction to stable-isotope analysis for seabird biologists: approaches, cautions and caveats. Mar Ornithol 37:183-188

Bowker GM (1980) Griffiths Island. Corella 4:104-6

Peer] reviewing PDF | (2019:09:41276:2:0:NEW 1 Feb 2020) 
502 Brooke MDL (2004) The food consumptions of the world's seabirds. PRSB Biol Sci 271:S246$503 \quad$ S248

504 Brothers N, Pemberton D, Pryor H, Halley V (2001) Tasmania's offshore islands: seabirds and 505 other natural features. Tasmanian Museum and Art Gallery: Hobart, Tasmania

506 Bunce A (2001) Prey consumption of Australasian gannets (Morus serrator) breeding in Port 507 Phillip Bay, southeast Australia, and potential overlap with commercial fisheries. ICES J Mar Sci 58:904-915

509

510

511

512

513

514

515

516

517 518

519

520

521

522

Bunce A, Norman FI, Brothers N, Gales R (2002) Long-term trends in the Australasian gannet (Morus serrator) population in Australia: the effect of climate change and commercial fisheries. Mar Biol 141: 263-269

Cai W (2006) Antarctic ozone depletion causes an intensification of the Southern Ocean supergyre circulation. Geophys Res Lett 33:L03712

Cai W, Shi G, Cowan T, Bi D, Ribbe J (2005) The response of the Southern Annular Mode, the East Australian Current, and the southern mid-latitude ocean circulation to global warming. Geophys Res Lett 32:L23706

Camprasse ECM, Sutton GJ, Berlincourt M, Arnould JPY (2017) Changing with the times: little penguins exhibit flexibility in foraging behaviour and low behavioural consistency. Mar Biol 164:169

Cavallo C, Chiaradia A, Deagle BE, McInnes JC, Sánchez S, Hays GC, Reina RD (2018) Molecular analysis of predator scats reveals role of salps in temperate inshore food webs. Front Mar Sci 5:381 
523 Chambers LE, Devney CA, Congdon BC, Dunlop N, Woehler E, Dann P (2011) Observed and

524 predicted effects of climate on Australian seabirds. Emu 111:235-251

525 Cherel Y, Bocher P, De Broyer C, Hobson KA (2002a) Food and feeding ecology of the 526 sympatric thin-billed prion Pachyptila belcheri and Antarctic P. Desolata prions at Iles Kerguelen, Southern Indian Ocean. Mar Ecol Prog Ser 228:263-281

528

529

530

531

532

533

534

535

536

537

538

539

540

541

542

543

Cherel Y, Bocher P, Trouvé C, Weimerskirch H (2002b) Diet and feeding ecology of blue petrels Halobaena caerulea at Iles Kerguelen, Southern Indian Ocean. Mar Ecol Prog Ser 228:283-299Cherel Y, Jaquemet S, Maglio A, Jaeger A (2014) Differences in $\delta^{13} \mathrm{C}$ and $\delta^{15} \mathrm{~N}$ values between feathers and blood of seabird chicks: implications for non-invasive isotopic investigations. Mar Biol 161:229-237

Cherel Y, Hobson KA (2007) Geographical variation in carbon stable isotope signatures of marine predators: a tool to investigate their foraging areas in the Southern Ocean. Mar Ecol Prog Ser 329:281-287

Cherel Y, Hobson KA, Guinet C, Vanpe C (2007) Stable isotopes document seasonal changes in trophic niches and winter foraging individual specialization in diving predators from the Southern Ocean. J Anim Ecol 76:826-836

Cherel Y, Hobson KA, Hassani S (2005a) Isotopic discrimination between food and blood and feathers of captive penguins: implications for dietary studies in the wild. Physiol Biochem Zool 78:106-115

Cherel Y, Hobson KA, Weimerskirch H (2005b) Using stable isotopes to study resource acquisition and allocation in procellariiform seabirds. Oecologia 145:533-540 
544 Cherel Y, Jaeger A, Alderman R, Jaquemet S, Richard P, Wanless RM, Phillips RA, Thompson

545 DR (2013) A comprehensive isotopic investigation of habitat preferences in nonbreeding 546 albatrosses from the Southern Ocean. Ecography 36:277-286

547 Chiaradia A, Costalunga A, Kerry K (2003) The diet of little penguins (Eudyptula minor) at 548 phillip island, victoria, in the absence of a major prey - pilchard (Sardinops sagax). Emu $549 \quad 103: 43-48$

550 Chiaradia A, Forero MG, Hobson KA, Cullen JM (2010) Changes in diet and trophic position of 551 a top predator ten years after a mass mortality of a key prey. ICES J Mar Sci 67:1710$552 \quad 1720$

553 Chiaradia A, Forero MG, Hobson KA, Swearer SE, Hume F, Renwick L, Dann P (2012) Diet 554 segregation between two colonies of little penguins Eudyptula minor in southeast $555 \quad$ Australia. Austral Ecol 37:610-619

556 Cleeland JB, Lea MA, Hindell MA (2014) Use of the Southern Ocean by breeding short-tailed 557 shearwaters (Puffinus tenuirostris). J Exp Mar Biol Ecol 450:109-117

558 Collins M, Cullen JM, Dann P (1999) Seasonal and annual foraging movements of little 559 penguins from Phillip Island, Victoria. Wildl Res 26:705-721

560 Croxall JP, Trathan PN, Murphy EJ (2002) Environmental change and Antarctic seabird 561 populations. Science 297:1510-1514

562 Cullen JM, Montague TL, Hull C (1992) Food of little penguins Eudyptula minor in Victoria: Comparison of three localities between 1985 and 1988. Emu 91:318-341 
564 Dann P, Norman FI (2006) Population regulation in little penguins (Eudyptula minor): the role of 565 intraspecific competition for nesting sites and food during breeding. Emu 106(4):269-289

566

567

568

569

570

571

572

573

574

575

576

577

578

579

580

581

582

583

Davies WE, Hipfner JM, Hobson KA, Ydenberg RC (2009) Seabird seasonal trophodynamics: isotopic patterns in a community of pacific alcids. Mar Ecol Prog Ser 382:211-219

Duffy DC, Jackson S (1986) Diet studies of seabirds: A review of methods. Colonial Waterbirds 9:1-17

Dunphy BJ, Taylor GA, Landers TJ, Sagar RL, Chilvers BL, Ranjard L, Rayner MJ (2015) Comparative seabird diving physiology: first measures of haematological parameters and oxygen stores in three New Zealand Procellariiformes. Mar Ecol Prog Ser 523:187-198

Einoder LD, Page B, Goldsworthy SD, De Little SC, Bradshaw CJA (2011) Exploitation of distant antarctic waters and close neritic waters by short-tailed shearwaters breeding in south australia. Austral Ecol 36:461-475

Espinoza P, Bertrand A, van der Lingen CD, Garrido S, Mendiola BR (2009) Diet of sardine (Sardinops sagax) in the northern Humboldt Current system and comparison with the diets of clupeoids in this and other eastern boundary upwelling systems. Prog in Oceano $83: 242-250$

Feng M, Caputi N, Pearce A (2012) The Leeuwin Current. In Poloczanska, ES, Hobday AJ, Richardson AJ (eds) A marine climate change impacts and adaptations report card for Australia 2012. Accessed 25 September 2012. www.oceanclimatechange.org.au

Fullagar PJ, Heyligers PC (1996) Gabo Island Shearwater Surveys, 1995 and 1996. 
584 Furlani D, Gales R, Pemberton D (2007) Otoliths of common australian temperate fish, Vol.

$585 \quad$ CSIRO Publishing, Collingwood

586 Gales R (1987) Validation of the stomach flushing technique for obtaining stomach contents of $587 \quad$ penguins. Ibis $129: 335-43$

588 Gales R, Pemberton D (1990) Seasonal and local variation in the diet of the little penguin, 589 Eudyptula minor, in Tasmania. Aust Wildlife Res 17:231-259

590 Gibbs CF (1992) Oceanography of Bass Strait: Implications for the food supply of little penguins 591 Eudyptula minor. Emu 91:395-401

592 Gibbs CF, Arnott GH, Longmore AR, Marchant JW (1991) Nutrient and plankton distribution 593 594 near a shelf break front in the region of the Bass Strait cascade. Aust J Mar Fresh Res $42: 201-217$

Gibbs CF, Tomczak Jr M, Longmore AR (1986) The nutrient regime of Bass Strait. Aust J Mar Fresh Res 37:451-466

597

598

599

600

601

602

603

604
Gill PC, Morrice MG, Page B, Pirzl R, Levings AH, Coyne M (2011) Blue whale habitat selection and within-season distribution in a regional upwelling system off southern Australia. Mar Ecol Prog Ser 421:243-263

González-Solís J, Croxall JP, Afanasyev V (2008) Offshore spatial segregation in giant petrels Macronectes spp.: Differences between species, sexes and seasons. Aquat Conserv: Mar Freshwat Ecosyst 17:S22-S36

Granroth-Wilding HMV, Phillips RA (2019) Segregation in space and time explains the coexistence of two sympatric sub-Antarctic petrels. Ibis 161:101-116 
605 Harper PC (1976) Breeding biology of the fairy prion (Pachyptila turtur) at the Poor Knights 606 Islands, New Zealand. N Z J Zool 3:351-371

607

608

609

610

611

612

613

614

615

616

617

618

619

620

621

622

623

624

Harper PC (1987) Feeding behaviour and other notes on 20 species of procellariiformes at sea. Notornis 34:169-192

Harris GP, Griffiths FB, Clementson LA, Lyne V, Van der Doe H (1991) Seasonal and interannual variability in physical processes, nutrient cycling and the structure of the food chain in Tasmanian shelf waters. J Plankton Res 13:109-131

Harris MP (1979) The seabirds of the Victorian islands. A report to the Ministry for Conservation, Victorian State Government. Institute for Terrestrial Ecology Project Report No. 588. Natural Environment Research Council

Hedd A, Gales R (2001) The diet of shy albatrosses (Thalassarche cauta) at Albatross Island, Tasmania. J. Zool. 253:69-90

Hobson KA (1993) Trophic relationships among high arctic seabirds: Insights from tissuedependent stable-isotope models. Mar Ecol Prog Ser 95:7-18

Hobson KA, Piatt JF, Pitocchelli J (1994a) Using stable isotopes to determine seabird trophic relationships. J Anim Ecol 63:786-798

Hobson KA, Piatt JF, Pitocchelli J (1994b) Using stable isotopes to determine seabird trophic relationships. J Anim Ecol 63:786-798

Hobson KA, Welch HE (1992) Determination of trophic relationships within a high Arctic marine food web using $\delta^{13} \mathrm{c}$ and $\delta^{15} \mathrm{n}$ analysis. Mar Ecol Prog Ser 84:9-18 
625 Jackson AL, Inger R, Parnell AC, Bearhop S (2011) Comparing isotopic niche widths among 626 and within com munities: SIBER - Stable Isotope Bayesian Ellipses in R. J Anim Ecol

627 80:595-602

628

629

630

631

632

633

634

635

636

637

638

639

640

641

642

643

644

Jaeger A, Connan M, Richard P, Cherel Y (2010) Use of stable isotopes to quantify seasonal changes of trophic niche and levels of population and individual specialisation in seabirds. Mar Ecol Prog Ser 401:269-277

Jakubas D, Wojczulanis-Jakubas K, Iliszko LM, Strøm H, Stempniewicz L (2017) Habitat foraging niche of a High Arctic zooplanktivorous seabird in a changing environment. Sci Rep 7:16203

Kokubun N, Yamamoto T, Sato N, Watanuki Y, Will A, Kitaysky AS, Takahashi A (2016) Foraging segregation of two congeneric diving seabird species breeding on St. George Island, Bering Sea. Biogeosiences 13:2579-2591

Layman CA, Arrington DA, Montaña CG, Post DM (2007) Can stable isotope ratios provide for community-wide measures of trophic structure? Ecology 88:42-48

Leitch TM, Dann P, Arnould JPY (2014) The diet of Pacific gulls (Larus pacificus) breeding at Seal Island in northern Bass Strait. Aus J Zool 62:216-222

Lu CC, Ickeringill R (2002) Cephalopod beak identification and biomass estimation techniques: Tools for dietary studies of southern Australian finfishes. Museum Victoria Science Reports No. 6. Museum Victoria, Fisheries Research and Development Corporation, Melbourne 
645 Marchant S, Higgins PJ (1990) Handbook of Australian, New Zealand and Antarctic birds, Vol.

646 1. Oxford University Press, Melbourne

647 Mickelson MJ, Dann P, Cullen JM (1992) Sea temperature in bass strait and breeding success of 648 the little penguin Eudyptula minor at Phillip Island, south-eastern australia. Emu 91:355$649 \quad 368$

650 Mills JA, Yarrall JW, Bradford-Grieve JM, Uddstrom MJ, Renwick JA, Merilä J (2008) The 651 impact of climate fluctuation on food availability and reproductive performance of the 652 plamktivorous red-billed gull Larus novaehollandiae scopulinus. J Anim Ecol 77:1129$653 \quad 1142$

654 Montague TL, Cullen JM, Fitzherbert K (1986) The diet of the short-tailed shearwater Puffinus 655 tenuirostris during its breeding season. Emu 86:207-213

656 Mori Y, Boyd I (2004) Segregation of foraging between two sympatric penguin species: does 657 rate maximization make the difference? Mar Ecol Prog Ser 275:241-249

658 Navarro J, Votier SC, Aguzzi J, Chiesa JJ, Forero MG, Phillips RA (2013) Ecological

659 segregation in space, time and trophic niche of sympatric planktivorous petrels. PLoS

660 ONE 8(4): e62897

661 Navarro J, Votier SC, Phillips RA (2014) Diving capabilities of diving petrels. Polar Biol

662 $37: 897-901$

663 Neira FJ, Miskiewicz AG, Trnski T (1998) Larvae of temperate australian fishes, Vol. University 664 of Western Australia Press, Nedlands, Western Australia 
665 O'Brien DP (1988) Surface schooling behaviour of the coastal krill Nyctiphanes australis

666 (Crustacea: Euphausiacea) off Tasmania, Australia. Mar Ecol Prog Ser 42:219-233

667 Payne MR, Prince PA (1979) Identification and breeding biology of the diving petrels

668

Pelecanoides georgicus and P. urinatrix exsul at South Georgia. NZ J Zool 6:299-318

669

670

671

672

673

674

675

676

677

678

679

680

681

682

683

684

Pescott TW (1976) Seabird islands No 27, Lady Julia Percy Island, Victoria. The Australian Bird bander 14(1):29-31

Phillips RA, Croxall JP, Silk JRD, Briggs DR (2008) Foraging ecology of albatrosses and petrels from South Georgia: Two decades of insights from tracking technologies. Aquat Conserv: Mar Freshwat Ecosyst 17:S6-S21

Phillips RA, Silk JRD, Croxall JP (2005) Foraging and provisioning strategies of the lightmantled sooty albatross at South Georgia: Competition and co-existence with sympatric pelagic predators. Mar Ecol Prog Ser 285:259-270

Phillips RA, Silk JRD, Phalan B, Catry P, Croxall JP (2004) Seasonal sexual segregation in two Thalassarche albatross species: Competitive exclusion, reproductive role specialization or foraging niche divergence? Proc R Soc Lond, Ser B: Biol Sci 271:1283-1291

Polito MJ, Trivelpiece WZ, Reiss CS, Trivelpiece SG, Hinke JT, Patterson WP, Emslie SD (2019) Intraspecific variation in a dominant prey species can bias marine predator dietary estimates derived from stable isotope analysis. Limnol Oceanogr Methods 17(4):292-303

Pratte I, Robertson GJ, Mallory ML (2017) Four sympatrically nesting auks show clear resource segregation in their foraging environment. MEPS 572:243-254 
685 Prince JD (2001) Ecosystem of the South East Fishery (Australia), and fisher lore. Mar Freshw 686 Res 52:431-439

687 Prince PA, Morgan RA (1987) Diet and feeding ecology of procellariiformes. In: Croxall JP (ed) 688 Seabirds: Feeding ecology and role in marine ecosystems. Cambridge University Press, $689 \quad$ Cambridge, p 135-171

690 Quillfeldt P, McGill RAR, Furness RW (2005) Diet and foraging areas of Southern Ocean 691 seabirds and their prey inferred from stable isotopes: Review and case study of wilson's 692 storm-petrel. Mar Ecol Prog Ser 295:295-304

693

694

695

696

697

698

699

700

701

702

703

704

R Development Core Team (2018) R: A language and environment for statistical computing, version 3.5.1. (R Foundation for Statistical Computing: Vienna)

Raymond B, Shaffer SA, Sokolov S, Woehler EJ, Costa DP, Einoder L, Hindell M, Hosie G, Pinkerton M, Sagar PM, Scott D, Smith A, Thompson DR, Vertigan C, Weimerskirch H (2010) Shearwater foraging in the Southern Ocean: the roles of prey availibility and winds. PLoS ONE 5(6):e10960

Reilly PN, Cullen JM (1981) The little penguin Eudyptula minor in Victoria, II: Breeding. Emu $81: 1-19$

Ridgeway KR, Condie SA (2004) The 5500-km-long boundary flow off western and southern Australia. J Geophys Res 109:C04017

Ridgeway KR, Godfrey JS (1997) Seasonal cycle of the East Australian Current. J Geophys Res $102: 22921-22936$ 
705 Ridoux V (1994) The diets and dietary segregation of seabirds at the subantarctic Crozet Island. $706 \quad$ Mar Ornithol 22:1-192

707 Ritz D, Swadling K, Hosie G, Cazassus F (2003) Guide to the zooplankton of south eastern 708 Australia. Fauna of Tasmania Committee, University of Tasmania, Hobart

709 Ropert-Coudert Y, Kato A, Chiaradia A (2009) Impact of small-scale environmental perturbations on local marine food resources: a case study of a predator, the little penguin. Proc Biol Sci 276:4105-4109

Ropert-Coudert Y, Wilson RP, Daunt F, Kato A (2004) Patterns of energy acquisition by a central place forager: benefits of alternating short and long foraging trips. Behav Ecol $15: 824-830$

Ross GJB, Burbidge AA, Brothers N, Canty P, Dann P, Fuller PJ, Kerry KR, Norman FI, Menkhorst PW, Pemberton D, Shaughnessy G, Shaughnessy PD, Smith GC, Stokes T, Tranter J (2001) The status of Australia's seabirds. In: Zann LP, Kailola P (eds) The state of the marine environment report for australia technical annex: 1 the marine environment. Ocean Rescue 2000, Department of the Environment, Sport and Territories, Canberra, $\mathrm{p}$ $167-182$

Sandery PA, Kämpf J (2005) Winter-spring flushing of Bass Strait, south-eastern Australia: A numerical modelling study. Estuar Coast Shelf Sci 63:23-31

Sandery PA, Kämpf J (2007) Transport timescales for identifying seasonal variation in Bass Strait, south-eastern Australia. Estuar Coast Shelf Sci 74:684-696

Schoener TW (1974) Resource partitioning in ecological communities. Science 185:27-39 
726 Schumann N, Arnould JPY, Dann P (2008) Diet of common diving-petrels (Pelecanoides

727

728

729

730

731

732

733

734

735

736

737

738

739

740

741

742

743

744

745 urinatrix urinatrix) in southeastern Australia during chick rearing. Waterbirds 31:620624

Schumann N, Dann P, Arnould JPY (2014) The significance of northern-central Bass Strait in south-eastern Australia as habitat for burrowing seabirds. Emu 114:234-240

Surman CA, Wooller RD (2003) Comparative foraging ecology of five sympatric terns at a subtropical island in the eastern indian ocean. J Zool Lond 259:219-230

Sutton GJ, Hoskins AJ, and Arnould JP (2015) Benefits of group foraging depend on prey type in a small marine predator, the little penguin. PLoS One 10:e0144297

Taylor AR, Dann P, Arnould JPY (2013) Timing of breeding and diet of the black-faced cormorant Phalacrocorax fuscescens. Mar Ornithol 41:23-27

Tollit DJ, Steward MJ, Thompson PM, Pierce GJ, Santos MB, Hughes S (1997) Species and size differences in the digestion of otoliths and beaks: Implications for estimates of pinniped diet composition. Can J Fish Aquat Sci 54:105-119

Underwood MP (2012) Does size matter? Sex differences in white-faced storm petrels' ecology. Deakin University, Australia

van der Lingen CD, Bertrand A, Bode A, Brodeur R, Cubillos LA, Espinoza P, Friedland K, Garrido S, Irigoien X, Miller T, Mollmann C, Rodriguez-Sanchez R, Tanaka H, Temming A (2009) Trophic dynamics in climate change and small pelagic fish, pp. 112157. Cambridge University Press, Cambridge, UK 
746 Vertigan CA (2010) The life-history of short-tailed shearwaters (Puffinus tenuirostris) in

747 response to spatio-temporal environmental variation. University of Tasmania, Tasmania

748 Wakefield ED, Bodey TW, Bearhop S, Blackburn J, Colhoun K, Davies R, Dwyer RG, Green

749 JA, Gremillet D, Jackson AL, Jessopp MJ, Kane A, Langston RHW, Lescroel A, Murray

750 S, Le Nuz M, Patrick SC, Peron C, Soanes LM, Wanless S, Votier SC, Hamer KC (2013)

751 Space partitioning without territoriality in gannets. Science 341(6141):68-70

752 Waugh SM, Weimerskirch H (2003) Environmental heterogeneity and the evolution of foraging

753 behaviour in long ranging greater albatrosses. Oikos 103:374-384

754 Weimerskirch H, Cherel Y (1998) Feeding ecology of short-tailed shearwaters: Breeding in

755 Tasmania and foraging in the Antarctic? Mar Ecol Prog Ser 167:261-274

756 Woehler EJ, Raymond B, Watts DJ (2006) Convergence or divergence: where do short-tailed

757 shearwaters forage in the Southern Ocean? MEPS 324:261-270

758 Woehler EJ, Patterson TA, Bravington MV, Hobday AJ, Chambers LE (2014) Climate and

759

$760 \quad 263$

761 Young JW, Jordan AR, Bobbi C, Johannes RE, Haskard K, Pullen G (1993) Seasonal and

762 interannual variability in krill (Nyctiphanes australis) stocks and their relationship to the

763 fishery for jack mackerel (Trachurus declivis) off eastern Tasmania, Australia. Mar Biol

$764 \quad 166: 9-18$ 
765 Zhang J, Rayner M, Vickers S, Landers T, Sagar R, Stewart J, Dunphy B (2018) GPS telemetry 766 for small seabirds: using hidden Markov models to infer foraging behaviour of common 767 diving petrels (Pelecanoides urinatrix urinatrix). Emu 119(2):126-137 


\section{Table $\mathbf{1}$ (on next page)}

Main species of seabirds breeding in Bass Strait, indicating the estimated number of breeding pairs, their proportion of the total Australian populations (based on Ross et al. 2001), and the major groups of prey consumed.

Some of the population estimates were not updated for at least three decades (e.g. Brothers et al. 2001) and may represent a source of error. 


\begin{tabular}{|c|c|c|c|c|}
\hline Species & $\begin{array}{c}\text { Abundance } \\
\text { (number of } \\
\text { breeding pairs) }\end{array}$ & $\begin{array}{l}\% \text { of the } \\
\text { Australian } \\
\text { population }\end{array}$ & Groups of main prey & Reference \\
\hline Shy albatross & 5200 & $35 \%$ & Fish/cephalopods & Alderman et al. 2011, Hedd \& Gales 2001 \\
\hline Short-tailed shearwater* & 14600000 & $75 \%$ & Crustaceans/Fish & Weimerskirch \& Cherel 1998, Brothers et al. 2001, Schumann et al. 2014 \\
\hline Common diving petrel* & 98500 & $63 \%$ & Crustaceans & Brothers et al. 2001, Schumann et al. 2008, Schumann et al. 2014 \\
\hline Fairy prion* & 97000 & $7 \%$ & Crustaceans & Brothers et al. 2001, Schumann et al. 2014 \\
\hline White-faced storm petrel & 94500 & $25 \%$ & Crustaceans & Brothers et al. 2001, Underwood 2012 \\
\hline Little penguin* & 353000 & $82 \%$ & Fish & Cullen et al. 1992, Brothers et al. 2001, Dann \& Norman 2006, Schumman et al. 2014 \\
\hline Australasian gannet & 16800 & $85 \%$ & Fish & Bunce et al. 2002, Bunce 2001 \\
\hline Black faced cormorant & 4400 & $55 \%$ & Fish & Brothers et al. 2001, Taylor et al. 2013 \\
\hline Pacific gull & 1500 & $82 \%$ & Scavenge - polyvorous & Brothers et al. 2001, Leitch et al. 2014 \\
\hline Silver gull & 50000 & $35 \%$ & Scavenge - polyvorous & Brothers et al. 2001, Leitch et al. 2014 \\
\hline Crested tern & 10400 & $13 \%$ & Fish & Brothers et al. 2001, Chiaradia et al. 2012 \\
\hline
\end{tabular}

*study species 


\section{Table 2 (on next page)}

Percentage of numerical abundance of the main groups of prey recovered from stomach contents of little penguins, short-tailed shearwaters, fairy prions and common diving petrels in Central Bass Strait. 
1

\begin{tabular}{ccccc}
\hline & $\begin{array}{c}\text { Little } \\
\text { penguin } \\
(\mathbf{n}=\mathbf{4 2})\end{array}$ & $\begin{array}{c}\text { Short-tailed } \\
\text { shearwater } \\
(\mathbf{n}=\mathbf{5 1})\end{array}$ & $\begin{array}{c}\text { Fairy prion } \\
(\mathbf{n}=\mathbf{2 0})\end{array}$ & $\begin{array}{c}\text { Common } \\
\text { diving petrel } \\
(\mathbf{n}=\mathbf{6})\end{array}$ \\
\hline Fish (\%) & 74.1 & 1.8 & $>0.1$ & - \\
Cephalopods (\%) & 4.8 & 0.2 & - & - \\
Crustaceans (\%) & 21.1 & 98.0 & 99.9 & 100
\end{tabular}

2 


\section{Table 3(on next page)}

Summer mean ( \pm SD) $\delta^{13} \mathrm{C}$ and $\delta^{15} \mathrm{~N}$ values $(\%)$ in whole blood and isotopic niche metrics of little penguins, short-tailed shearwaters and fairy prions from western, central and eastern Bass Strait.

The samples were collected in summer (January-February) 2009, 2010 and 2011. 


\begin{tabular}{|c|c|c|c|c|c|c|c|c|c|c|}
\hline & & \multicolumn{3}{|c|}{ Western Bass Strait } & \multicolumn{3}{|c|}{ Central Bass Strait } & \multicolumn{3}{|c|}{ Eastern Bass Strait } \\
\hline & & Little penguin & $\begin{array}{c}\text { Short-tailed } \\
\text { shearwater }\end{array}$ & Fairy prion & Little penguin & $\begin{array}{c}\text { Short-tailed } \\
\text { shearwater }\end{array}$ & Fairy prion & Little penguin & $\begin{array}{l}\text { Short-tailed } \\
\text { shearwater }\end{array}$ & Fairy prion \\
\hline \multirow{3}{*}{$\begin{array}{l}\delta^{13} \mathbf{C} \\
(\%)\end{array}$} & 2009 & $\begin{array}{c}-19.1 \pm 0.4 \\
(\mathrm{n}=10)\end{array}$ & $\begin{array}{c}-21.9 \pm 0.4 \\
(\mathrm{n}=16)\end{array}$ & $\begin{array}{c}-19.2 \pm 0.2 \\
(\mathrm{n}=8)\end{array}$ & $\begin{array}{c}-19.8 \pm 0.1 \\
(\mathrm{n}=18)\end{array}$ & $\begin{array}{c}-22.2 \pm 0.3 \\
(\mathrm{n}=20)\end{array}$ & - & $\begin{array}{c}-19.0 \pm 0.3 \\
(\mathrm{n}=18)\end{array}$ & $\begin{array}{c}-22.9 \pm 0.5 \\
(\mathrm{n}=20)\end{array}$ & - \\
\hline & 2010 & $\begin{array}{c}-19.5 \pm 0.2 \\
(\mathrm{n}=20)\end{array}$ & $\begin{array}{c}-23.1 \pm 0.3 \\
(\mathrm{n}=20)\end{array}$ & $\begin{array}{c}-19.5 \pm 0.6 \\
(\mathrm{n}=10)\end{array}$ & $\begin{array}{c}-20.1 \pm 0.4 \\
(\mathrm{n}=19)\end{array}$ & $\begin{array}{c}-22.2 \pm 0.3 \\
(\mathrm{n}=20)\end{array}$ & $\begin{array}{c}-20.5 \pm 0.7 \\
(\mathrm{n}=6)\end{array}$ & $\begin{array}{c}-19.0 \pm 0.2 \\
(\mathrm{n}=20)\end{array}$ & $\begin{array}{c}-22.1 \pm 0.4 \\
(\mathrm{n}=20)\end{array}$ & - \\
\hline & 2011 & $\begin{array}{c}-18.9 \pm 0.3 \\
(\mathrm{n}=20)\end{array}$ & $\begin{array}{c}-21.9 \pm 0.4 \\
(\mathrm{n}=20)\end{array}$ & $\begin{array}{c}-18.8 \pm 0.4 \\
(\mathrm{n}=18)\end{array}$ & $\begin{array}{c}-19.9 \pm 0.2 \\
(\mathrm{n}=10)\end{array}$ & $\begin{array}{c}-22.0 \pm 0.3 \\
(\mathrm{n}=20)\end{array}$ & $\begin{array}{c}-19.8 \pm 0.3 \\
(\mathrm{n}=17)\end{array}$ & $\begin{array}{c}-18.5 \pm 0.2 \\
(\mathrm{n}=10)\end{array}$ & $\begin{array}{c}-21.1 \pm 0.5 \\
(\mathrm{n}=13)\end{array}$ & - \\
\hline \multirow{3}{*}{$\begin{array}{l}\delta^{15} \mathbf{N} \\
(\%)\end{array}$} & 2009 & $\begin{array}{c}15.5 \pm 0.3 \\
(\mathrm{n}=10)\end{array}$ & $\begin{array}{l}9.5 \pm 0.6 \\
(\mathrm{n}=16)\end{array}$ & $\begin{array}{c}13.7 \pm 0.6 \\
(\mathrm{n}=8)\end{array}$ & $\begin{array}{c}14.4 \pm 0.2 \\
(\mathrm{n}=18)\end{array}$ & $\begin{array}{l}9.3 \pm 0.7 \\
(\mathrm{n}=20)\end{array}$ & - & $\begin{array}{c}12.9 \pm 0.9 \\
(\mathrm{n}=18)\end{array}$ & $\begin{array}{c}9.4 \pm 0.6 \\
(\mathrm{n}=20)\end{array}$ & - \\
\hline & 2010 & $\begin{array}{c}13.2 \pm 0.9 \\
(\mathrm{n}=20)\end{array}$ & $\begin{array}{c}8.5 \pm 0.4 \\
(n=20)\end{array}$ & $\begin{array}{c}13.6 \pm 0.9 \\
(\mathrm{n}=10)\end{array}$ & $\begin{array}{c}13.4 \pm 0.5 \\
(\mathrm{n}=19)\end{array}$ & $\begin{array}{l}8.6 \pm 0.5 \\
(\mathrm{n}=20)\end{array}$ & $\begin{array}{c}11.7 \pm 0.8 \\
(\mathrm{n}=6)\end{array}$ & $\begin{array}{c}13.6 \pm 0.3 \\
(\mathrm{n}=20)\end{array}$ & $\begin{array}{l}8.8 \pm 0.3 \\
(\mathrm{n}=20)\end{array}$ & - \\
\hline & 2011 & $\begin{array}{c}15.0 \pm 0.4 \\
\mathrm{n}=(20)\end{array}$ & $\begin{array}{c}9.7 \pm 0.6 \\
(\mathrm{n}=20)\end{array}$ & $\begin{array}{c}12.5 \pm 0.9 \\
(\mathrm{n}=18)\end{array}$ & $\begin{array}{c}14.9 \pm 0.3 \\
(\mathrm{n}=10)\end{array}$ & $\begin{array}{l}9.9 \pm 0.6 \\
(\mathrm{n}=20)\end{array}$ & $\begin{array}{c}13.2 \pm 0.5 \\
(\mathrm{n}=17)\end{array}$ & $\begin{array}{c}13.6 \pm 0.2 \\
(\mathrm{n}=10)\end{array}$ & $\begin{array}{l}9.9 \pm 0.7 \\
(\mathrm{n}=13)\end{array}$ & - \\
\hline
\end{tabular}




\section{Table 4 (on next page)}

Winter mean $\left( \pm\right.$ SD) $\delta^{13} \mathrm{C}$ and $\delta^{15} \mathrm{~N}$ values $(\%)$ in whole blood and isotopic niche metrics of little penguins, fairy prions and common diving petrels from western, central and eastern Bass Strait.

The samples were collected in winter (July-August) 2008, 2009 and 2010. 
1

\begin{tabular}{|c|c|c|c|c|c|c|c|c|c|c|}
\hline & & \multicolumn{3}{|c|}{ Western Bass Strait } & \multicolumn{3}{|c|}{ Central Bass Strait } & \multicolumn{3}{|c|}{ Eastern Bass Strait } \\
\hline & & Little penguin & Fairy prion & $\begin{array}{c}\text { Common } \\
\text { diving petrel }\end{array}$ & Little penguin & Fairy prion & $\begin{array}{c}\text { Common } \\
\text { diving petrel }\end{array}$ & Little penguin & Fairy prion & $\begin{array}{c}\text { Common } \\
\text { diving petrel }\end{array}$ \\
\hline \multirow{3}{*}{$\begin{array}{l}\delta^{13} \mathrm{C} \\
(\%)\end{array}$} & 2008 & $\begin{array}{c}-19.2 \pm 0.4 \\
(\mathrm{n}=3)\end{array}$ & - & - & $\begin{array}{c}-19.0 \pm 0.3 \\
(\mathrm{n}=7)\end{array}$ & - & $\begin{array}{c}-20.8 \pm 0.8 \\
(\mathrm{n}=10)\end{array}$ & - & - & - \\
\hline & 2009 & $\begin{array}{c}-20.0 \pm 0.4 \\
(n=2)\end{array}$ & - & - & $\begin{array}{c}-19.7 \pm 0.1 \\
(\mathrm{n}=20)\end{array}$ & - & $\begin{array}{c}-20.8 \pm 0.2 \\
(\mathrm{n}=4)\end{array}$ & $\begin{array}{c}-19.3 \pm 0.5 \\
(\mathrm{n}=20)\end{array}$ & - & - \\
\hline & 2010 & $\begin{array}{c}-19.3 \pm 0.6 \\
(\mathrm{n}=16)\end{array}$ & $\begin{array}{c}-19.2 \pm 0.4 \\
(\mathrm{n}=18)\end{array}$ & $\begin{array}{c}-19.6 \pm 0.1 \\
(\mathrm{n}=8)\end{array}$ & $\begin{array}{c}-19.8 \pm 0.1 \\
(\mathrm{n}=20)\end{array}$ & $\begin{array}{c}-19.5 \pm 0.3 \\
(\mathrm{n}=3)\end{array}$ & $\begin{array}{c}-20.9 \pm 0.3 \\
(\mathrm{n}=15)\end{array}$ & $\begin{array}{c}-19.2 \pm 0.3 \\
(\mathrm{n}=20)\end{array}$ & - & - \\
\hline \multirow{3}{*}{$\begin{array}{l}\delta^{15} \mathbf{N} \\
(\%)\end{array}$} & 2008 & $\begin{array}{c}13.0 \pm 0.1 \\
(\mathrm{n}=3)\end{array}$ & - & - & $\begin{array}{c}14.4 \pm 0.4 \\
(\mathrm{n}=7)\end{array}$ & - & $\begin{array}{c}12.0 \pm 1.1 \\
(\mathrm{n}=10)\end{array}$ & - & - & - \\
\hline & 2009 & $\begin{array}{c}13.3 \pm 0.4 \\
(\mathrm{n}=2)\end{array}$ & - & - & $\begin{array}{c}15.0 \pm 0.4 \\
(\mathrm{n}=20)\end{array}$ & - & $\begin{array}{c}14.3 \pm 0.2 \\
\quad(\mathrm{n}=4)\end{array}$ & $\begin{array}{c}13.1 \pm 1.2 \\
(\mathrm{n}=20)\end{array}$ & - & - \\
\hline & 2010 & $\begin{array}{c}13.2 \pm 0.6 \\
(\mathrm{n}=16)\end{array}$ & $\begin{array}{c}11.4 \pm 1.4 \\
(\mathrm{n}=18)\end{array}$ & $\begin{array}{c}11.6 \pm 0.3 \\
(\mathrm{n}=8)\end{array}$ & $\begin{array}{c}14.2 \pm 0.3 \\
(\mathrm{n}=20)\end{array}$ & $\begin{array}{c}12.2 \pm 0.3 \\
(\mathrm{n}=3)\end{array}$ & $\begin{array}{c}12.2 \pm 0.2 \\
(\mathrm{n}=15)\end{array}$ & $\begin{array}{c}13.3 \pm 0.6 \\
(\mathrm{n}=20)\end{array}$ & - & - \\
\hline
\end{tabular}

2 


\section{Figure 1}

Simplified representation of the three study areas and the major water masses influencing the region.

Western Bass Strait (WBS); Central Bass Strait (CBS); Eastern Bass Strait (EBS); Lady Julia Percy Island (LJPI); Norman Island (Norl); Kanowna Island (KI); Answer Island (AI); Notch Island (Notl); Gabo Island (GI); South Australian Current (SAC); Sub-Antarctic Surface Water (SASW); East Australian Current (EAC) from Sandery \& Kämpf 2005. The solid line indicates the location of the $300 \mathrm{~m}$ isobath. 


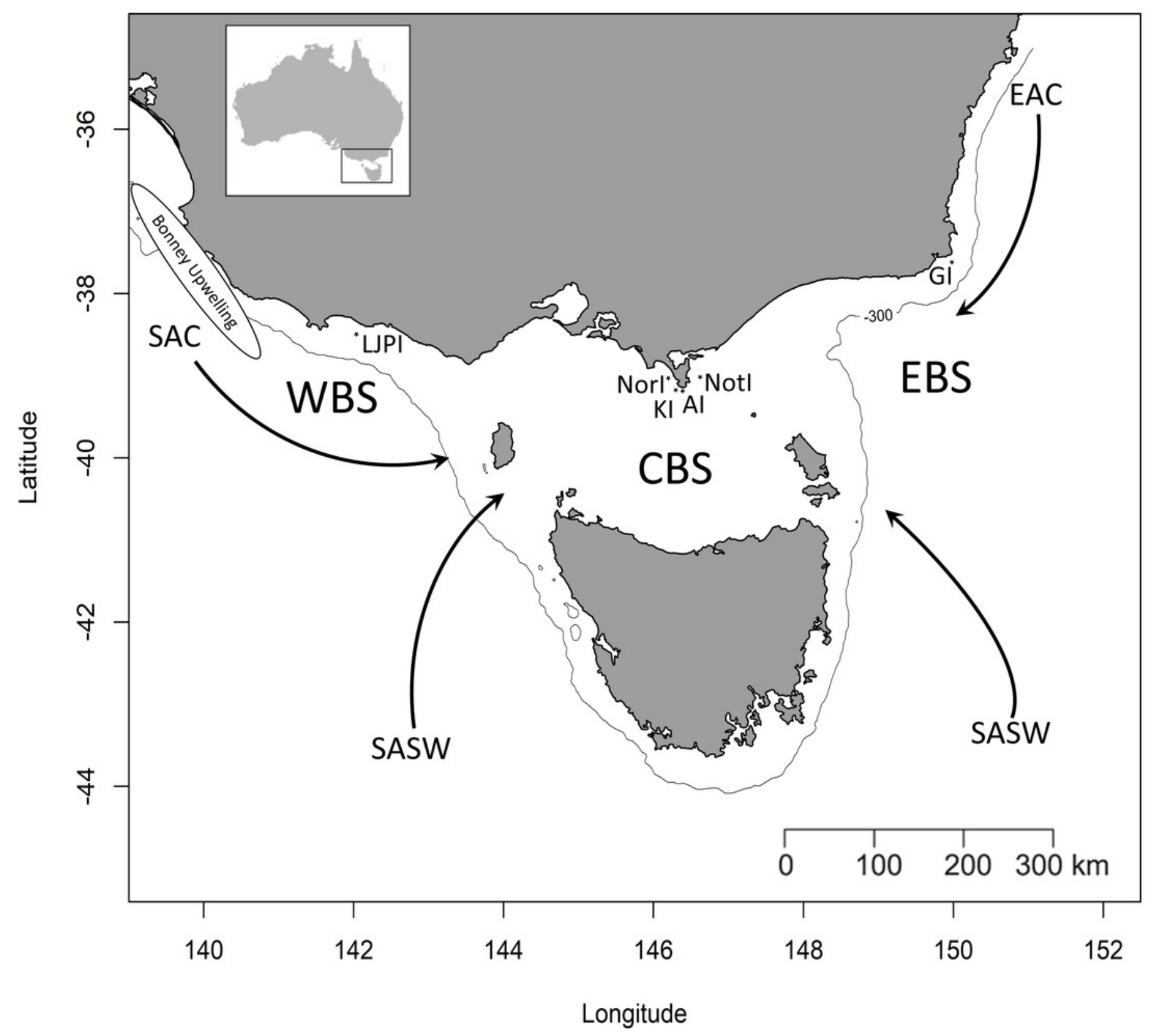


Figure 2

Phenology and sampling period of little penguin (LP), short-tailed shearwater (STSW), fairy prion (FP) and common diving petrel (CDP) in Bass Strait.

Blocks with vertical and horizontal lines correspond to incubation and chick-rearing period, respectively. Grey shaded blocks correspond to the winter and summer sampling periods.

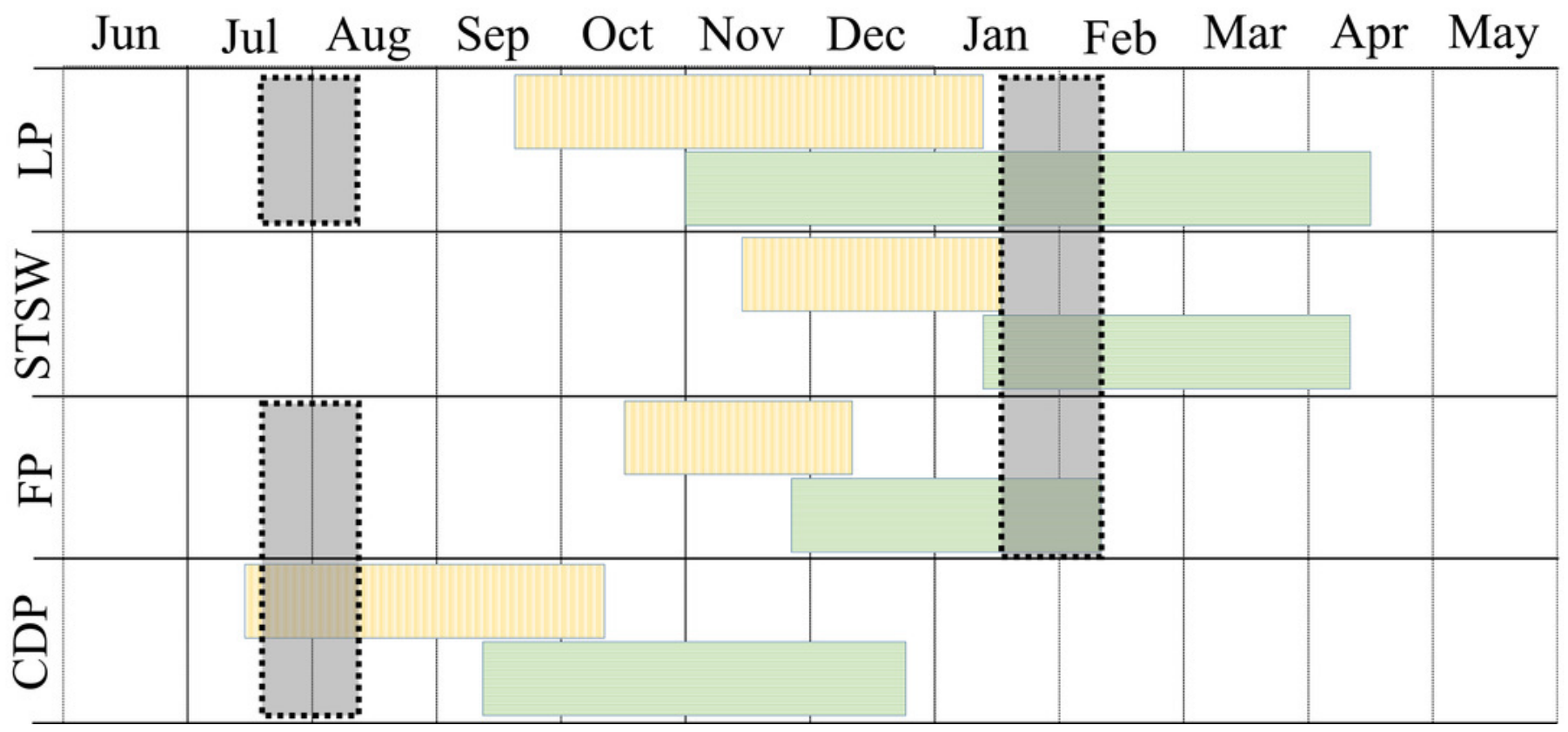


Figure 3

Summer inter-annual variation of $\delta^{13} \mathrm{C}$ and $\delta^{15} \mathrm{~N}$ values $(\%)$ in whole blood of little penguins $(A, B, C)$, short-tailed shearwaters $(D, E, F)$ and fairy prions $(G, H)$ : western Bass Strait (WBS), central Bass Strait (CBS) and eastern Bass Strait

Solid lines represent the standard ellipses corrected for sample size (SEAc) based on $\delta^{13} \mathrm{C}$ and $\delta^{15} \mathrm{~N}$ values in summer 2009, 2010 and 2011. Note that the ranges for $x$ and $y$ axes are different for each species. 


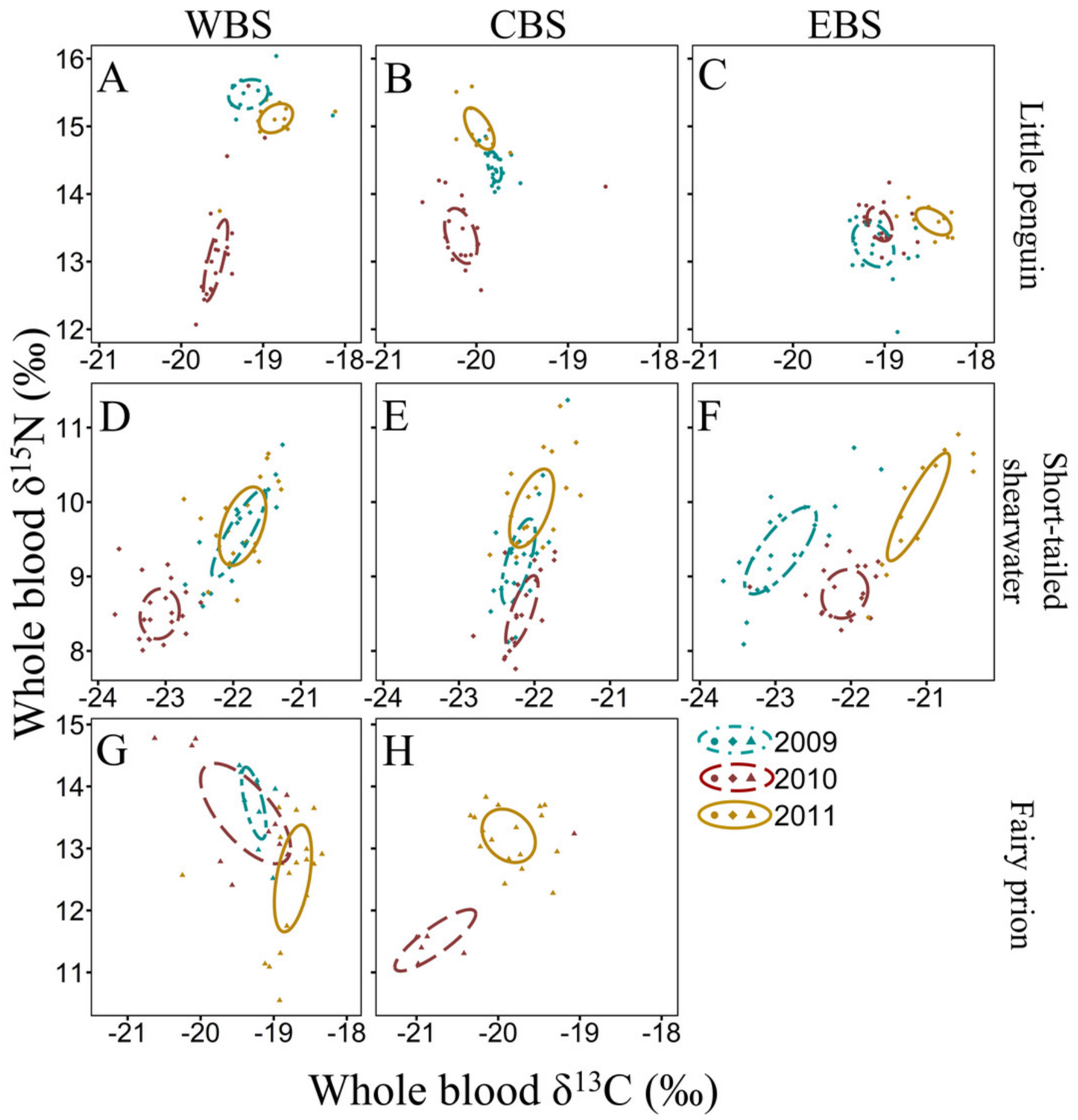


Figure 4

Winter inter-annual variation of $\delta^{13} \mathrm{C}$ and $\delta^{15} \mathrm{~N}$ values (\%) in whole blood of little penguins $(A, B, C)$ and common diving petrels $(D, E)$ : western Bass Strait (WBS), central Bass Strait (CBS) and eastern Bass Strait (EBS).

Solid lines represent the standard ellipses corrected for sample size (SEAC) based on $\delta^{13} \mathrm{C}$ and $\delta^{15} \mathrm{~N}$ values in winter 2008, 2009 and 2010. Note that the range for $x$ and $y$ axes are different for each species.

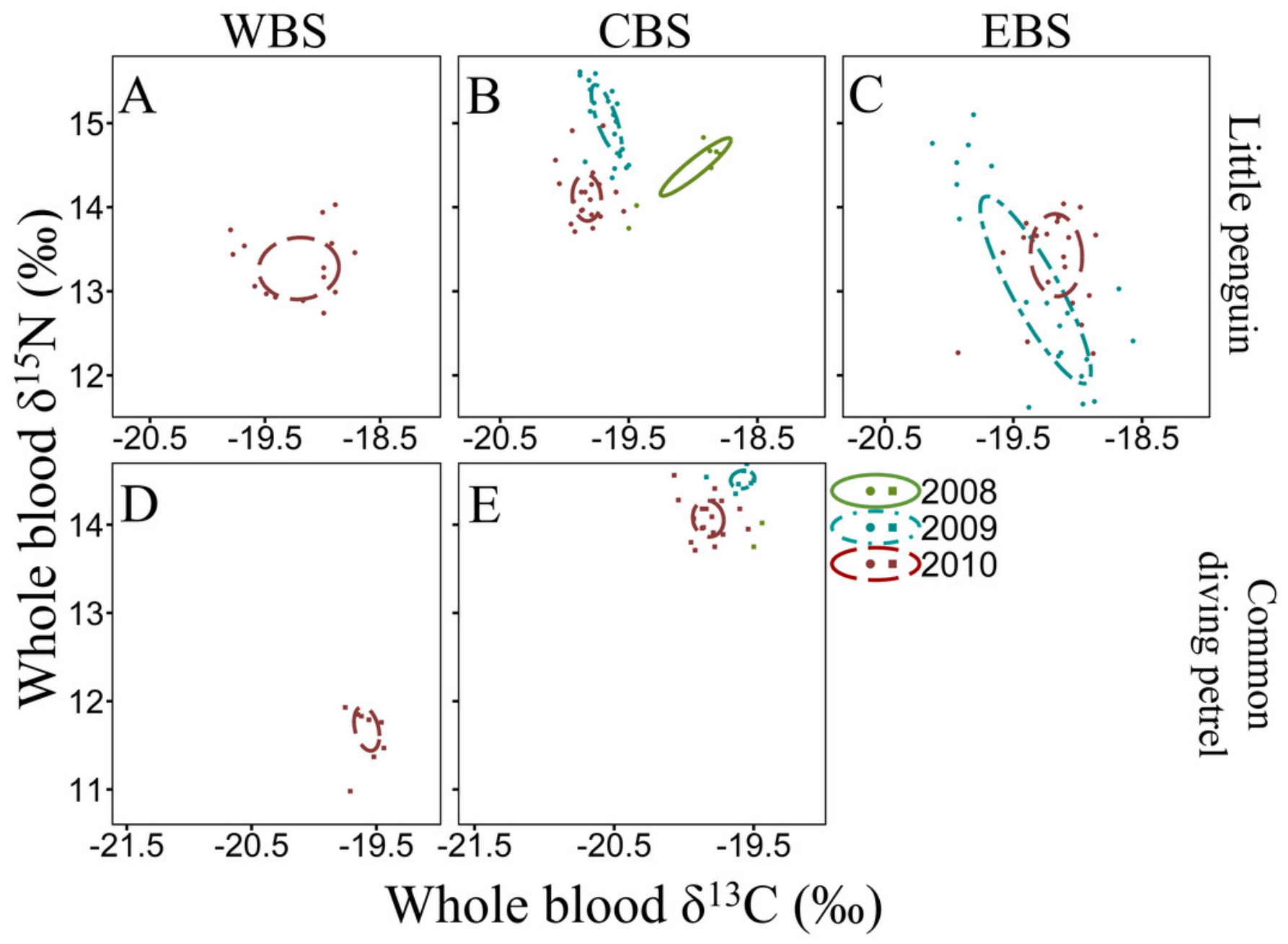




\section{Figure 5}

Summary of $\delta^{13} \mathrm{C}$ and $\delta^{15} \mathrm{~N}$ values (\%o) in whole blood of the main marine predators in Bass Strait region.

Little penguin ( $L P, n=278$; present study; summer and winter combined), short-tailed shearwater (STSW, $n=177$; present study; summer and winter combined), fairy prion (FP, $n$ $=88$; present study; summer and winter combined), common diving petrel $(C D P, n=38$; present study; summer and winter combined), Australasian gannet (GA, $n=27$; Angel et al. 2016; summer), white-faced storm petrel (WFST, $n=17$; Underwood 2012; summer), shy albatross (SA, $n=8$; Cherel et al. 2013; summer) and Australian fur seal (AFS, $n=242$; Arnould et al. 2011; winter). The isotopic values of WFST and SA were calculated from data on chick feathers (Underwood 2012) and adult feathers (Cherel et al. 2013), respectively, and corrected using mean correction factors in Cherel et al. 2014. 


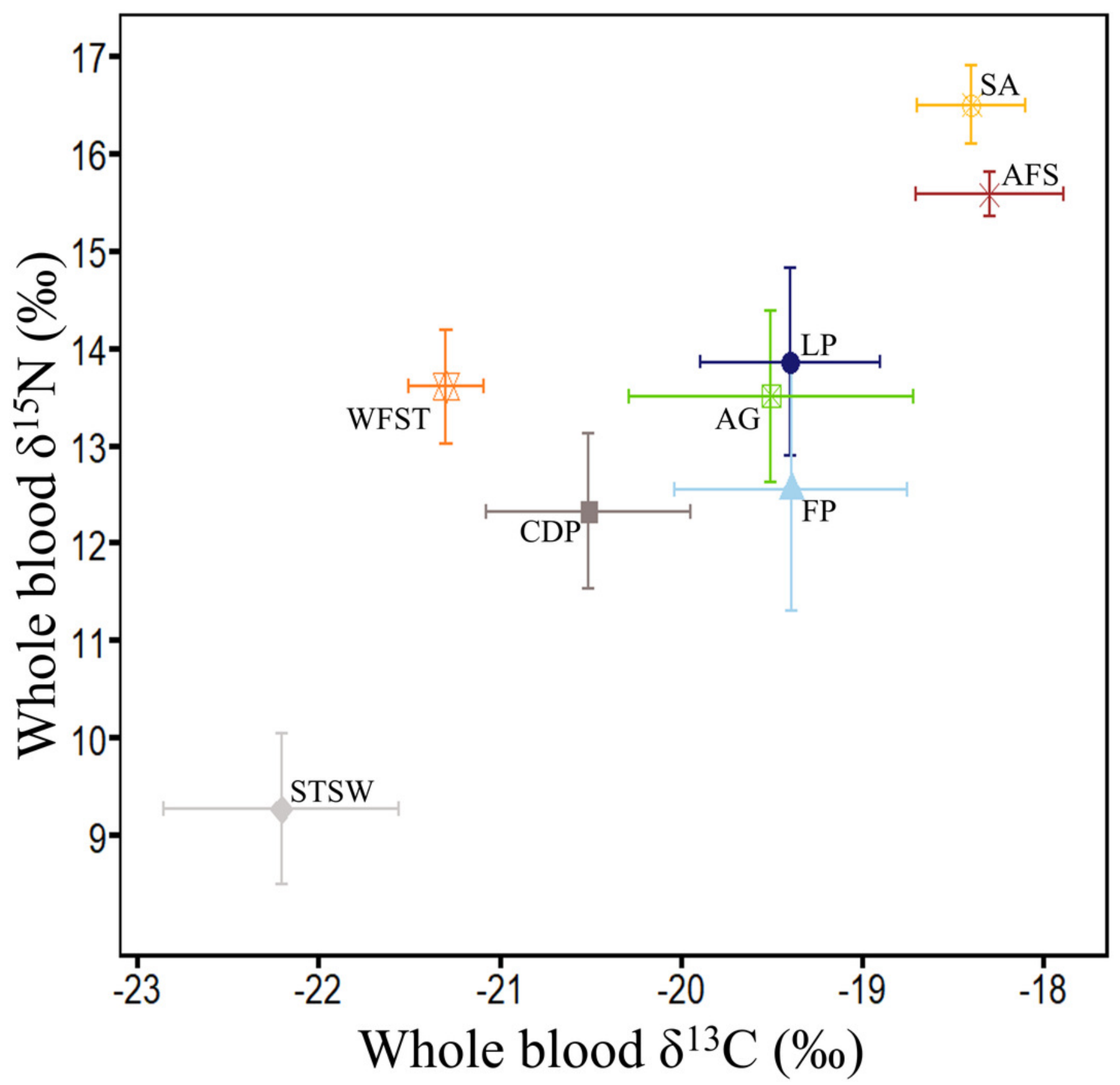

